\title{
David Oliver: Stop blaming patients for emergency visits
}

\author{
David Oliver consultant in geriatrics and acute general medicine, Berkshire
}

The NHS Wales chief is urging patients "not to clog up accident and emergency units," the BBC recently reported. ${ }^{1}$ The story? Four fifths of patients using emergency departments didn't need hospital admission or treatment. The inference? Such attendances were frivolous, entirely avoidable, or irresponsible. The Welsh "Choose Well” programme, reasonably enough, aims to steer patients to appropriate services. ${ }^{2}$ But the message that stuck from the BBC's story was one of blaming patients.

NHS England's review of urgent care also described alternative options for patients, from "self care" upwards. ${ }^{3}$ But the mass media focused on Bruce Keogh, medical director of NHS England, saying that $40 \%$ of patients leave emergency departments without treatment. ${ }^{4}$

Several local service leaders have mirrored this line. For instance, Barnsley Hospital reported a survey of 951 such patients. Only $22 \%$ considered their condition to be an emergency, and many admitted that attendance was merely the quickest route to assessment. ${ }^{5}$ But how representative were the respondents? Numerous hospitals have mounted local campaigns encouraging people to stay away.

Activity in UK emergency departments is at a record high. ${ }^{6}$ Overcrowding is a serious risk to patients. ${ }^{7}$ Departments are understaffed and the workforce stretched. Acute hospitals are being hammered from government and regulators about four hour performance that they only partly control.

A report from the Royal College of Emergency Medicine and the Patients Association, Time to Act, surveyed 924 emergency patients. ${ }^{8}$ It concluded, "The judgement of urgent and emergency is made by the patient and not by the clinician." Patients' highest preference was still the hospital emergency department: as one said, "When in doubt, frightened or worried, I'd use A\&E."

Many patients attended the emergency department through personal choice, but $40 \%$ had been advised to attend by a healthcare provider such as a GP. One third had already consulted another service before resorting to an emergency department. About two thirds were well aware of other services such as general practice, out of hours, or pharmacists.
The Department of Health is pushing an agenda of choice. ${ }^{9}$ The public are intelligent. They know that they're likely to be seen and treated within four hours in emergency departments, 24/7. Many have less confidence in alternative community services, often from personal experience. And many people, frightened that they are seriously ill, want reassurance-also known as leaving with no medical treatment. The College of Emergency Medicine has now called for co-location of urgent primary care centres with emergency departments. ${ }^{10}$

Blaming the public for using a service that they value, when they think it's needed, is the antithesis of patient centredness. Punishing emergency departments for demand is unhelpful.

Competing interests: I have read and understood the BMJ policy on declaration of interests and have no relevant interests to declare. Provenance and peer review: Commissioned; not externally peer reviewed.

Follow David on Twitter, @mancunianmedic

1 "Think" plea to avoid A\&E winter crisis in Wales. BBC News 2015 Oct 26. www.bbc.co. uk/news/uk-wales-34615902?ns_mchannel=social\&ns_campaign=bbc_wales_news\&ns_ source=twitter\&ns_linkname=wales.

2 NHS Direct Wales. Choose Well. www.nhsdirect.wales.nhs.uk/choosewell/.

3 NHS England. Urgent and emergency care review: end of phase 1 report. 13 Nov 2013. www.nhs.uk/NHSEngland/keogh-review/Documents/UECR.Ph1Report.Appendix\%201. EvBase.FV.pdf.

4 Boseley S, Wintour P. NHS plan to concentrate specialist A\&E expertise in fewer hospitals. Guardian 2013 Nov 13. www.theguardian.com/society/2013/nov/12/plan-a-and-e-crisis.

5 Barnsley Hospital NHS Foundation Trust. Report shows only $22 \%$ of people attending Barnsley's emergency department think it's an emergency. 7 Oct 2014. www.

barnsleyhospital.nhs.uk/news/report-shows-22-people-attending-barnsleys-emergencydepartment-think-emergency/.

6 Blunt I. Focus on: A\&E attendances. Nuffield Trust. 24 Jul 2014. www.nuffieldtrust.org. uk/publications/focus-on-ae-attendances.

7 NHS England. Safer, faster, better: good practice in delivering urgent and emergency care. Aug 2015. www.england.nhs.uk/wp-content/uploads/2015/06/trans-uec.pdf.

8 Royal College of Emergency Medicine, Patients Association. Time to act-urgent care and A\&E: the patient perspective. May 2015. www.rcem.ac.uk/Shop-Floor/Policy/Reports/ Time\%20to\%20Act\%20(2015).

9 Hunt J. HSJ annual lecture: full transcript. Health Serv J 2015 Oct 29. www.hsj.co.uk/ news/hsj-annual-lecture-full-transcript/5091559.article?blocktitle=Latest-news\& contentID=15964.

10 Roberts N. Emergency doctors call for co-location of GPs and A\&E. GP Online 2014 Nov 25. www.gponline.com/emergency-doctors-call-co-location-gps-a-e/article/1323609. 
